\title{
TRADISI JUAL BELI ANAK DI KABUPATEN PADANG PARIAMAN PERSPEKTIF AL-'URF DAN HUKUM PIDANA
}

\author{
Taufik Hidayat1, Yusri Amir ${ }^{2}$ Yovidal Yazid ${ }^{3}$, Arif Fansuri4 \\ 1 Universitas Islam Negeri Imam Bonjol Padang \\ e-mail: taufiiq_hidaayah@Yahoo.com \\ 2 Universitas Islam Negeri Imam Bonjol Padang \\ e-mail: yusriamir86@yahoo.co.id \\ 3 Universitas Islam Negeri Imam Bonjol Padang \\ e-mail: yovidaly@gmail.com \\ ${ }^{4}$ Kejaksaan Negeri Padang Panjang \\ e-mail: ari.ffansuri@gmail.com
}

\begin{abstract}
The tradition of "buying and selling" children in the community of Padang Pariaman Regency is a habit that has been passed down for generations. Though Islamic law and Indonesian criminal law forbid "buying and selling" children. This research is an empirical legal research by looking at the phenomenon of the tradition of "buying and selling" children in Padang Pariaman Regency. Then, it was analyzed with al-'urf in Islamic law and elements of criminal acts in Indonesian criminal law. Based on the results of research that the purpose of the tradition of "buying and selling" children in Padang Pariaman Regency is to eliminate the bad luck of a child by bis biological parents. This in Islamic law belongs to al-furf al-fasid. So that despite the sale and purchase of children in Padang Pariaman Regency, this tradition is not included in the crime of trafficking of children, because it does not fulfill the elements of the crime of child trafficking.
\end{abstract}

Kata kunci: jual beli, anak, al-urf, hukum Pidana.

\section{PENDAHULUAN}

$\mathcal{A}$ nak adalah amanah dan karunia Allah SWT. Kehadiran anak dinantinantikan oleh setiap keluarga baru sebagai penerus keturunan mereka. Tangisan bayi yang baru lahir akan disambut dengan penuh gembira dan harapan oleh kedua orang tuanya. Secara indah hal ini digambarkan oleh al-Qur'an dalam bentuk do'a-do'a orang tua (MUI \& UNICEF, 1988: 3). Allah berfirman dalam al-Qur'an surat 'Ali Imran ayat 38:

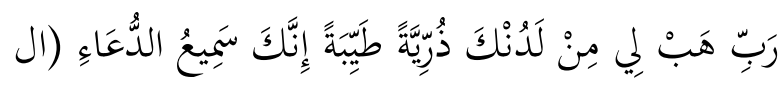

(بر : عمران

"Ya Tuhanku, berilah aku dari sisi engkau seorang anak yang baik" (Q.S. Ali 'Imrân [3]: 38)

Kata dzurriyyatan thayyibatan dalam Tafsir as-Tsa'labi al-Kasyfu wa al-Bayân adalah keturunan yang shaleh, bertakwa, menyenangkan, dan diberkahi (AsTsa'labi, 2000: III: 29). Sedangkan dalam tafsir-tafsir lain, anak yang baik ditafsirkan sebagai anak yang shaleh (alQurtubî, 2003: 72). 
Anak yang shaleh akan didapatkan dari perawatan dan pembinaan yang baik dari kedua orang tua serta perlindungan dari berbagai macam keburukan yang akan membahayakan anak. Dalam kaitan ini, negara Republik Indonesia telah membuat aturan khusus untuk melindungi anak dari berbagai bentuk kejahatan, baik dari kedua orang tuanya maupun orang lain. Aturan khusus itu adalah UU No. 23 Tahun 2002 tentang Perlindungan Anak, UU No. 35 Tahun 2014 tentang Perubahan Pertama UU No. 23 Tahun 2002 tentang Perlindungan Anak UU No. 17 Tahun 2016 tentang Penetapan Peraturan Pemerintah Pengganti UU No. 1 Tahun 2016 tentang Perubahan Kedua Atas UU No. 23 Tahun 2002 tentang Perlindungan Anak.

Pasal 76F UU No. 35 Tahun 2014 tentang Perubahan Pertama UU No. 23 Tahun 2002 tentang Perlindungan Anak menyebutkan: "Setiap orang dilarang menempatkan, membiarkan, melakukan, menyuruh melakukan, atau turut serta melakukan penculikan, penjualan, dan/atau perdagangan anak". Ketentuan sanksinya dapat kita lihat dalam Pasal 83: "Setiap orang yang melanggar ketentuan sebagaimana dimaksud dalam Pasal 76F dipidana dengan pidana penjara paling singkat 3 (tiga) tahun dan paling lama 15 (lima belas) tahun dan denda paling sedikit Rp. 60.000.000,00 (enam puluh juta rupiah) dan paling banyak Rp. 300.000.000,00 (tiga ratus juta rupiah)."

UU secara tegas telah melarang penjualan dan/atau memperdagangkan anak yang diikuti dengan hukuman yang berat bagi pelakunya. Kenyataannya perdagangan anak tersebut masih tetap ada. Terbukti dengan banyaknya berita yang keluar di media masa. Perdagangan anak menjadi permasalahan yang serius baik pada skala nasional maupun internasional (Indrawati, 2015: 37).

Adapun faktor-faktor yang melatarbelakangi kasus perdagangan anak (child trafficking) antara lain: kurangnya kesadaran, kemiskinan, keinginan cepat kaya, faktor budaya, kurangnya pencatatan kelahiran, kurangnya pendidikan, korupsi dan lemahnya penegakan hukum (www.kpai.go.id).

Jika faktor-faktor yang melatarbelakangi kasus perdagangan anak menurut KPAI (Komisi Perlindungan Anak Indonesia) ini diamati lebih lanjut, maka dapat dipahami secara umum bahwa motivasi dalam perdagangan anak adalah uang. Kemiskinan menjadi faktor utama dalam perdagangan anak (Putri, 2017: 1).

Berbeda dengan kasus-kasus jual beli anak yang pada umumnya dimotivasi oleh uang, masyarakat Kabupaten Padang Pariaman juga melakukan jual beli anak demi kebaikan anaknya dan ini telah menjadi sebuah tradisi. Praktik jual beli anak yang sudah menjadi tradisi ini dapat dipahami dari kegiatan masyarakat Kabupaten Padang Pariaman yang melakukakannya secara turun temurun, artinya mereka menjual anaknya karena dahulu mereka juga dijual oleh orang tuanya.

Tradisi jual beli anak yang dilakukan masyarakat Kabupaten Padang Pariaman berawal dari dua alasan, yaitu: pertama ketika anak serupa (mirip) dengan ayahnya dan kedua ketika anak mengalami penyakit yang tidak kunjung sembuh. Kedua alasan inilah yang menyebabkan para orang tua menjual anaknya kepada orang lain.

Hal yang menjadi permasalahan dalam tradisi jual beli anak di Kabupaten 
Padang Pariaman ini adalah apakah tradisi jual beli anak ini termasuk tindak pidana perdagangan manusia sebagaimana yang diatur dalam Pasal 76F UU No. 35 Tahun 2014 tentang Perubahan Pertama UU No. 23 Tahun 2002 tentang Perlindungan Anak?

Selanjutnya, jika tradisi jual beli anak ditinjau dari aturan jual beli dalam hukum Islam, apakah tradisi ini termasuk kedalam tradisi yang dibenarkan ('urf shahih) atau termasuk ke dalam tradisi yang telah rusak ('urffasid)?

Kondisi ini memunculkan keraguan dalam memahami tradisi jual beli anak yang dilakukan oleh sebagian masyarakat Kabupaten Padang Pariaman, karena masyarakat Minangkabau adalah masyarakat muslim yang harus mempunyai tradisi yang dibenarkan oleh syari'ah ('urf shahih) dan terhindar dari setiap tradisi yang telah rusak ("urf fasid). Oleh karena itu perlu penelitian yang lebih lajut bagaimana perspektif al'urf dan hukum pidana tentang tradisi jual beli anak di Kabupaten Padang Pariaman.

\section{METODE PENELITIAN}

Jenis penelitian ini adalah penelitian hukum empiris atau disebut juga penelitian hukum sosiologis. Adapun lokasi penelitian hukum empiris ini adalah Kabupaten Padang Pariaman, karena fenomena tradisi jual beli anak ini ditemukan dalam tradisi masyarakat Kabupaten Padang Pariaman. Sumber data yang dibutuhkan dalam penelitian tradisi jual beli anak ini terklasifikasi menjadi dua sumber data, yaitu: sumber data primer dan sumber data sekunder.

Sumber data primer adalah data yang diperoleh atau dikumpulkan langsung di lapangan. Data primer disebut juga data asli atau data baru, seperti: hasil wawancara dengan masyarakat yang melakukan jual beli anak dan wawancara dengan tokoh masyarakat tentang jual beli anak.

Sedangkan data sekunder adalah data yang diperoleh dan dikumpulkan dari sumber-sumber yang telah ada. Data sekunder disebut juga data yang tersedia (Hasan, 2002: 82) seperti undang-undang, buku-buku, artikel dari media masa dan bahan informasi lainnya yang berkaitan dengan masalah penelitian. Di dalam penelitian hukum, data sekunder mencakup (Soekanto, 2006: 13): Pertama, bahan hukum primer (primer sources or authorities), yaitu bahan-bahan hukum yang mengikat dan merupakan norma atau kaidah dasar. Adapun bahan hukum primer dalam hukum Islam yang akan dipergunakan dalam penelitian ini ialah yaitu an-Nushush (al-Qur'an dan asSunnah) sebagai dalil yang disepakati oleh ulama dalam menganalisa permasalahan hukum. Sedangkan dalam analisa hukum pidana peneliti mengacu pada KUHP sebagai ketentuan umum tentang tindak pidana jual beli anak dan ketentuan khusunya yaitu: UU No. 9 Tahun 1999 tentang Hak Asasi Manusia, UU No. 26 Tahun 2000 tentang Pengadilan Hak Asasi Manusia, UU No. 21 Tahun 2007 tentang Pemberantasan Tindak Pidana Perdagangan Orang, UU No 23 Tahun 2002 tentang Perlindungan Anak dan UU No.35 Tahun 2014 tentang Perubahan Pertama UU No.23 Tahun 2002 tentang Perlindungan Anak.

Kedua, bahan hukum sekunder (secondary sources or authorities), yang memberikan penjelasan mengenai bahan hukum primer. Dalam penelitian ini 
bahan hukum sekunder yang akan digunakan seperti penjelasan undangundang, hasil penelitian hukum oleh para ilmuan hukum. Dalam hukum Islam penjelasan dari norma dasar (al-Qur'an dan Hadis) ditemui dalam kitab-kitab tafsir, kitab-kitab ushûl figh dan kitab-kitab figh hasil karya dari kalangan fuqahấ serta ilmuan hukum lainya.

Ketiga, bahan hukum tersier (tertier sources or authorities), yakni bahan yang memberikan petunjuk maupun penjelasan terhadap bahan hukum primer dan sekunder, contohnya adalah kamus hukum, ensikplopedi hukum.

Data yang diperoleh baik dari penelitian lapangan maupun dari studi kepustakaan akan dianalisis secara deskriptif kualitatif. Analisis deskriptif kualitatif yaitu metode analisis data yang mengelompokkan dan menyeleksi data yang diperoleh dari penelitian lapangan menurut kualitas dan kebenarannya, kemudian dihubungkan dengan teoriteori, asas-asas, dan kaidah-kaidah hukum yang diperoleh dari studi kepustakaan sehingga diperoleh jawaban atas permasalahan yang dirumuskan.

Analisa terakhir penelitian ini adalah analisa Ushul Figh dan hukum pidana terhadap data dan temuan di lapangan. Analisa Ushul Figh, yaitu penggunaan kaidah-kaidah Ushul Figh dalam rangka mengistinbathkan hukum. Dalam penelitian ini, kaidah yang digunakan adalah kaidah al-'urf, yakni menghubungkan data dan temuan di lapangan dengan nash (alQur'an, as-Sunnah) untuk menyimpullkan apakah tradisi jual beli anak di Kabupaten Padang Pariaman dapat dikategorikan al'urf as-shahih (adat yang dibenarkan ajaran syari'at Islam) atau al-'urf al-fasid (adat yang tidak dibenarkan ajaran syari'at Islam).

Dalam menganalisa tradisi jual beli anak dari segi hukum pidana mengacu kepada KUHP dan aturan-aturan khusus di luar KUHP yaitu: UU No. 9 Tahun 1999 tentang Hak Asasi Manusia, UU No. 26 Tahun 2000 tentang Pengadilan Hak Asasi Manusia, UU No. 21 Tahun 2007 tentang Pemberantasan Tindak Pidana Perdagangan Orang, UU No 23 Tahun 2002 tentang Perlindungan Anak dan UU No.35 Tahun 2014 tentang Perubahan Pertama UU No.23 Tahun 2002 tentang Perlindungan Anak. Langkah dalam analisa ini adalah menelusuri semua unsur-unsur tindak pidana yang terdapat pada tindak pidana perdagangan anak yang akhirnya akan menyimpulkan apakah tradisi jual beli anak di Kabupaten Padang Pariaman merupakan perbuatan yang termasuk kategori tindak pidana atau tidak.

\section{MAKNA DAN LATAR BELAKANG TRADISI JUAL BELI ANAK DI KABUPATEN PADANG PARIAMAN}

Pengertian tradisi jual beli anak dapat dipahami dari segi kebahasaan. Kata "Tradisi" berarti kebiasan masyarakat, kata "Jual beli" berarti menukar sesuatu dengan sesuatu, dan kata "Anak" di sini dimaksudkan anak manusia. Secara sederhana tradisi jual beli anak itu adalah kebiasaan masyarakat yang menukar anaknya dengan sesuatu. Jadi, tradisi jual beli anak itu dipahami kebiasaan masyarakat Kabupaten Padang Pariaman yang menukarkan anak kandungnya dengan sesuatu yang diberikan oleh pembelinya.

Secara terminologi, pengertian jual beli anak yang telah diperoleh dari hasil 
wawancara yang dilakukan terhadap tokoh masyarakat dan pelaku tradisi jual beli anak tersebut. Mereka memberikan redaksi yang berbeda dalam mengemukakan pengertian tradisi jual beli anak tersebut, namun mengacu kepada dua pemahaman.

Pemahaman pertama, bahwa tradisi jual beli anak itu adalah pemindahan kondisi tidak baik seorang anak oleh orang tua kandungnya kepada seseorang, disebabkan orang tua kandungnya itu tidak dapat memberikan rezki dan kebaikan bagi anak kandungnya. Seseorang yang dimaksudkan itu adalah orang yang dinilai mampu memberikan rezki kepada anak tersebut. Berdasarkan makna ini bahwa hakikat jual beli anak itu adalah memindahkan keadaan yang tidak baik seorang anak oleh orang tua kandungnya kepada orang lain. Adapun tujuan tradisi itu adalah untuk memberikan rezki dan kebaikan kepada anak yang dijual tersebut. Pengertian ini memberikan pemahaman bahwa anak yang dijual itu tidak akan mendapatkan rezki dan kebaikan jika masih milik orang tua kandungnya. Karena itu, anak itu harus dijual agar dia memperoleh rezki dan kebaikan.

Pemahaman kedua, bahwa tradisi jual beli anak itu ialah menjual anak kepada orang-orang yang mempunyai kelebihan dikarenakan anak itu sakit, nakal, bodoh dan berpenyakit diganggu oleh setan, contohnya adalah jika anak itu nakal maka dijual kepada Tuangku (ahli agama), dengan tujuan agar anak itu hormat kepada ayah barunya yang merupakan ulama dan mendapatkan berkah dari ayahnya. Jika anak itu sering sakit dijual kepada orang yang banyak memiliki anak karena orang itu dianggap mampu dan pandai dalam mengasuh anak. Lebih dari itu, melalui jual beli anak itu akan terjalin hubungan silaturrahmi dengan ayah dan ibu baru anak yang dijual.

Makna tradisi jual beli anak yang dijelaskan di atas menitikberatkan kepada kriteria orang membeli anak dan penyebab melakukan tradisi jual beli anak tersebut. Kriteria orang yang membeli itu adalah orang-orang yang mempunyai kelebihan. Sedangkan penyebab tradisi jual beli anak itu adalah kondisi anak yang dijual dalam keadaaan sakit, nakal, bodoh dan berpenyakit diganggu oleh setan.

Berdasarkan pengertian di atas dapat dipahami bahwa makna tradisi jual beli anak itu adalah: kebiasaan masyarakat yang telah turun temurun untuk menjual anak kandungnya kepada orang lain bukan untuk tujuan komersial akan tetapi untuk memindahkan status kepemilikan anaknya, karena diyakini akan memindahkan rezeki yang diterima oleh anak dari orang tua kandungnya kepada orang tua angkat yang telah membelinya.

Penjelasan di atas memberi penegasan bahwa makna tradisi jual beli anak di Kabupaten Padang Pariaman adalah kebiasaan masyarakat Kabupaten Padang Pariaman dalam rangka menghilangkan atau membuang nasib buruk seorang anak oleh orang tua kandungnya. Jadi, tradisi jual beli anak di Kabupaten Padang Pariaman bukanlah kebiasaan jual beli yang berlaku pada umumnya. Karena itu, pada hakikatnya tradisi jual beli anak di Kabupaten Padang Pariaman tidak mengalami pemindahan kepemilikan anak dari orang tua 
kandungnya kepada orang lain yang bertindak sebagai pembeli.

Bukti tradisi jual beli anak itu tidak mengalami pemindahan kepemilikan dapat dilihat dari keadaan setelah jual beli itu dilaksanakan. Pertama, anak yang dijual itu tetap berada dalam pengasuhan orang tua. Kedua, orang tua kandung anak yang dijual tetap berkewajiban menafkahi anak tersebut.

Berdasarkan penelusuran peneliti kepada tokoh masyarakat dan pelaku tradisi jual beli anak di Kabupaten Padang Pariaman tidak diperoleh penjelasan yang pasti kapan tradisi ini dimulai untuk pertama kalinya. Selain itu, juga tidak diketahui secara pasti daerah mana yang pertama kali memulai tradisi jual beli anak ini. Informasi yang didapatkan dari mereka melalui wawancara bahwa tradisi jual beli anak ini sudah terjadi sejak nenek moyang mereka. Sebagai bukti bagi mereka bahwa tradisi ini sudah berlangsung lama adalah kasus tradisi jual beli anak ini mereka alami secara turun temurun, seperti ungkapan mereka "Saya telah menjual anak saya, saya pun dijual oleh orang tua saya dan orang tua saya dijual pula oleh kakek saya", begitu seterusnya. Ungkapan ini disampaikan oleh mayoritas masyarakat sebagai pelaku tradisi jual beli anak di Kabupaten Padang Pariaman.

Walaupun kondisinya demikian, namun peneliti mendapatkan keterangan dari beberapa masyarakat yang memberikan penjelasan tentang kemungkinan yang melatarbelakngi tradisi jual beli anak di Kabupaten Padang Pariaman. Pertama, keterangan yang mengatakan bahwa tradisi jual beli anak itu merupakan paham yang berasal dari ajaran Tarikat Syathariyyah yang terdapat di Kabupaten
Padang Pariaman. Indikasi tradisi jual beli anak ini ajaran Tarikat Syathariyah adalah mayoritas pelaku tradisi ini merupakan penganut tarikat tersebut, baik penjual atau pembelinya. Bahkan, para penjual anak tersebut sangat berkeinginan jika pembelinya adalah Tuangku (sebuatan untuk tokoh Tarikat Syathariyah). Di samping itu, para Tuangku pun banyak bertindak sebagai pembeli anak dalam tradisi jual beli anak ini.

Setelah dilakukan penelusuran kepada pihak Tarikat Syathariyah, mereka membantah bahwa tradisi jual beli anak itu adalah ajaran Tarikat Syathariyah. Tradisi jual beli anak itu hanyalah budaya masyarakat Kabupaten Padang Pariaman yang telah terjadi secara turun temurun sejak nenek moyang dahulu, namun tidak diketahui kapan mulainya, siapa yang pertama kali mencetuskan dan di mana daerah yang pertama kali melaksanakannya. Penjualan anak kepada Tuangku adalah untuk mempererat hubungan ukhuwah Islamiyah karena terjalin ikatan antara keluarga yang menjual anaknya dengan keluarga pembeli. Selain itu, masyarkat yang melaksanakan tradisi jual beli anak itu, terutama penjual, menginginkan anaknya sehat secara jasmani dan rohani. Hal ini dapat mereka peroleh pada sosok Tuangku, maka inilah yang memotivasi mereka untuk menjual anaknya kepada para Tuangku.

Kedua, tradisi jual beli anak di Kabupaten Padang Pariaman kemungkinan besar dilatarbelakangi oleh pengetahuan ajaran agama Islam yang minim pada masyarakat terhadap hal-hal yang menjerumuskan kepada perbuatan syirik (mempersekutukan Allah). Berdasarkan informasi yang diperoleh dari masyarakat yang melakukan tradisi jual beli anak di 
Kabupaten Padang Pariaman maka hal itu benar adanya. Ungkapan yang dikemukakan oleh pelaku tradisi jual beli anak bahwa cara menghilangkan kondisi tidak baik pada anak hanya dengan menjual anak tersebut dan itu mereka yakini. Mereka menyebutkan bahwa anak yang sering sakit itu hanya bisa disembuhkan dengan menjualnya dan anak laki-laki yang mirip ayahnya rezkinya tidak bagus jika rezkinya melalui ayahnya tersebut, maka solusi rezki anak itu dengan menjualnya. Inilah yang dipahami masyarakat Kabupaten Padang Pariaman tentang tradisi jual beli anak, bahkan sudah menjadi keyakinan. Pemahaman seperti inilah yang menjerumuskan mereka kepada perbuatan mempersekutukan Allah sebagai Tuhan mereka.

Ketiga, tradisi jual beli anak di Kabupaten Padang Pariaman terindikasi sebagai kebiasaan yang terjadi sejak masyarakat Hindu zaman dahulu sampai sekarang. Indikasi tradisi jual beli anak itu merupakan budaya Hindu zaman dahulu adalah adanya perpindahan status anak secara batin dari orang tua kandungnya kepada orang yang membeli anak tersebut. Faktor lain yang mendukung hal ini adalah persyaratan yang mengharuskan membawa nasi kunyit ketika orang tua kandung anak yang dijual ingin mengembalikan harga jual anak tersebut. Pada zahirnya nasi itu kami yang memakannya dan pada batinnya (secara ghaib) makhluk haluslah yang memakan nasi kunyik itu.

Dengan demikian, tradisi jual beli anak itu terlaksana secara zahir dan secara batin. Secara zahir dilakukan oleh manusia dan secara batin dilakukan oleh makhluk halus. Hal ini memberi pemahaman bahwa tradisi jual beli anak sudah ada dan berkembang pada masa Hindu, karena pemahaman seperti itu merupakan keyakinan masyarakat Hindu. Adanya syarat memberikan makanan (sesajen) berupa nasi kunyit yang diperuntukkan kepada makhluk halus. Sesajen ini menjadi suatu kewajiban bagi orang tua kandung yang ingin mengambil (menebus) anak yang telah dijual. Pemberian makanan (sesajen) berupa nasi kunyit kepada makhluk halus itu merupakan keyakinan dan perbuatan masyarakat Hindu.

Kondisi seperti ini bisa dibenarkan secara fakta sejarah, karena ajaran dan keyakinan Hindu lebih dahulu hidup dan berkembang pada masyarakat Kabuapaten Padang Pariaman dari pada ajaran agama Islam. Karena itu, pengaruh keyakinan Hindu masih terdapat pada masyarakat Kabupaten Padang Pariaman sekalipun mereka sudah beragama Islam. Dengan demikian dapat disimpulkan bahwa tradisi jual beli anak di Kabupaten Padang Pariaman dilatarbelakangi oleh pengaruh keyakinan Hindu yang masih hidup dan berkembang di tengah masyarakat.

\section{PRAKTIK TRADISI JUAL BELI ANAK DI KABUPATEN PADANG PARIAMAN}

Praktik tradisi jual beli anak di Kabupaten Padang Pariaman tidak berbeda dengan pelaksanaan jual beli pada umumnya yang terdiri dari empat rukun yaitu: para pihak yang bertransaksi, siqhat, barang yang diperjual belikan dan nilai tukar barang pengganti barang. (Zuhaili, 2005: 6) 
Adapun penjelasannya adalah sebagai berikut:

1. Penjual.

Penjual adalah orang yang memindahkan nasib buruk anaknya kepada orang lain. Penjual pada tradisi jaul beli anak ini merupakan orang tua kandung dari anak yang dijual. Pada umumnya tradisi jual beli anak di Kabupaten Padang Pariaman dilakukan oleh ibu anak dan sedikit yang dilakukan oleh ayah anak. Adapun alasan orang tua kandung melakukan tradisi jual beli anak adalah sebagai berikut:

a. Anak sering sakit-sakitan

b. Anak nakal

c. Anak bodoh

d. Anak diganggu setan,

e. Anak laki-laki mirip ayahnya dan anak perempuan mirip ibunya.

2. Pembeli.

Pembeli adalah orang yang bertindak sebagai orang tua angkat dalam tradisi jual beli anak. Pembeli ini merupakan orang-orang yang mempunyai kelebihan, seperti:

a. Orang tua "paiduik anak", yaitu orang yang mempunyai banyak anak dan diyakini sebagai orang mempunyai nasib baik dalam pemeliharaan anak.

b. Tuangku, yaitu alim ulama di Kabupaten Padang Pariaman yang telah menamatkan kaji (belajar) di pondok pesantren salafiyah/klasik yang berada di Kabupaten Padang Pariaman. Masyarakat sangat menghargai Tuangku, karena dianggap sebagai orang saleh dan berprilaku baik serta diyakini dapat merubah nasib anak yang dijual disebabkan kenakalan dan kebodohannya. c. Bako, yaitu orang yang berada di pihak keluarga ayah bagi anak yang dijual. Bako diyakini dapat merubah nasib anak laki-laki mirip ayahnya dan anak perempuan mirip ibunya.

3. Alat tukar atau harga

Alat tukar yang dipakai dalam tradisi jual beli anak di Kabupaten Padang Pariaman, yaitu:

a. Uang. Penggunaan uang dalam tradisi jual beli anak di Kabupaten Padang Pariaman hanya sekedar syarat bukan untuk tujuan komersial. Ini tergambar dari jumlah uang yang dipakai pada pelaksanaan jual beli hanya ala kadarnya, pada kisaran Rp. 1000,- (seribu rupiah) sampai Rp.50.000,- (lima puluh ribu rupiah)

b. Benda atau barang. Benda atau barang yang dipakai dalam pelaksanaan tradisi jual beli anak di Kabupaten Padang Pariaman berupa makanan, seperti beras, cabe dan bawang.

4. Akad yang terdiri ijab dan qabul.

Akad yang dipakai pada tradisi jual beli anak di Kabupaten Padang Pariaman sama halnya dengan akad jual beli pada umumnya. Sebagai contoh adalah:

a. Penjual. "Balilah anak den ko a karano we e sakik-sakik taghuih je nyeh"! (Belilah anak saya ini karena dia sering sakit-sakitan)

b. Pembeli. "Adih nah den bali anakko saharago limo ibu pitih jo bagheh satekong, untuang-untuang we e cegak" (Saya beli anak ini dengan harga Rp.5000,- semoga dia sembuh).

5. Barang yang diperjualbelikan

Barang yang diperjualbelikan pada tradisi jual beli anak di Kabupaten 
Padang Pariaman adalah anak yang masih kecil sampai anak itu menikah.

\section{TRADISI JUAL BELI ANAK DI KABUPATEN PADANG PARIAMAN DARI PERSPEKTIF AL-'URF DAN HUKUM PIDANA}

Faktor yang menentukan dalam penilaian sebuah tradisi atau kebiasaan pada syariat Islam adalah ada atau tidak adanya dukungan dari syara' terhadap tradisi tersebut. Jika tradisi itu mendapat dukungan dari syara' maka tradisi itu dinilai sebagai al-'Urf Shahih (tradisi baik) oleh syariat Islam dan begitu juga sebaliknya. Tradisi yang ada dukungan syara' yang dimaksudkan adalah kebiasaan yang berlaku ditengah-tengah masyarakat yang tidak bertentangan dengan al-Quran atau hadits (Miharja, 2011: 117), tidak menghilangkan kemaslahtan mereka, dan tidak pula membawa mudarat kepada mereka (Hamzawi, 2018: 8). Al-'urf yang seperti inilah yang dapat dijadikan landasan hukum, sebagaimana tertuang dalam kaidah "al-'Adah Muhakkamah". (Hidayat dan Daipon, 2018: 108) Jadi, tolak ukur utama dalam penilaian tradisi adalah tidak bertentangan dengan ketentuan yang telah ditetapkan al-Quran dan Hadits. Setelah itu, penilai tradisi itu dilihat dari segi tujuannya yaitu mendatang kemaslahatan bagi pelaku tradisi tersebut.

Masyarakat Kabupaten Padang Pariaman yang menjual anaknya meyakini bahwa anaknya telah bernasib sial jika bersamanya oleh sebab itulah mereka menjual anaknya kepada orang lain agar anaknya bernasib baik dan terhindar dari sekalian kemudaratan yang telah menimpanya seperti: sakit yang tak kunjung sembuh. Walaupun tujuannya baik akan tetapi tradisi ini belum bisa dikategorikan tradisi yang dibenarkan oleh syari'at ('urf shahih) yang bersumber dari al-Qur'an dan as-Sunnah.

Jika dilihat dari segi dukungan syara' (al-Quran dan as-Sunnah), tradisi jual beli anak di Kabupaten Padang Pariaman dapat dikemukakan sebagai berikut:

a. Segi Barang yang Diperjualbelikan.

Pelaksanaan tradisi jual beli anak di Kabupaten Padang Pariaman sebagaimana dijelaskan terdahulu memenuhi semua unsur pelaksanaan jual beli pada umumnya, namun jika diamati unsur-unsur jual beli yang terdapat dalam tradisi jual beli anak itu maka ada unsur yang tidak sesuai dengan ketentuan jual beli dalam Islam, yaitu seorang anak sebagai barang yang diperjualbelikan. Dalam jual beli Islam, barang yang diperjualbelikan adalah harta sedangkan seorang anak bukanlah termasuk kategori harta. Oleh sebab itu, Islam tidak membolehkan memperjualbelikan seorang anak sebagaimana ketentuan Islam yang menghapus perbudakan, karena diperbudakan itu terjadi jual beli manusia. Dengan demikian, tradisi jual beli anak di Kabupaten Padang Pariaman yang menjadi anak sebagai objek jual beli tidak sesuai dengan ketentuan Islam.

b. Segi Keyakinan Masyarakat.

Keyakinan masyarakat dalam tradisi jual beli anak di Kabupaten Padang Pariaman ini adalah untuk menghilangkan nasib buruk yang ada pada anak yang dijual. Keyakinan yang 
tertanam pada masyarakat bahwa nasib buruk itu hanya bisa dibuang dengan menjual anak tersebut. Kenyakinan seperti ini bukan tidak beralasan, karena masyarakat telah berupaya merubah nasib itu secara normal namun tidak diperoleh perubahannya tetapi setelah menjual anaknya perubahan nasib anaknya diperoleh.

Berkaitan dengan perubahan nasib buruk yang dialami anak dalam tradisi jual beli anak di Kabupaten Padang Pariaman terdapat beberapa keyakinan. Pertama, keyakinan kesembuhan anak yang sering sakit hanya diperoleh melalui tradisi jual beli anak. Keyakinan seperti ini sudah membudaya di tengah masyarakat Kabupaten Padang Pariaman, sehingga solusi yang tertanam dalam pemahaman masyarakat ketika anak sering sakitsakitan adalah melakukan tradisi jual beli anak. Kondisi ini tidak hanya terdapat pada orang tua anak yang sakit tetapi juga orang yang berada di sekitar mereka, sehingga dorongan untuk melakukan tradisi jual beli anak sangat kuat. Keyakinan seperti ini jelas bertentangan dengan ketentuan syari'at Islam. Islam memberikan keyakinan dan pemahaman bahwa sakit dan kesembuhan sesorang berada di kekuasaan Allah. Hal ini teruang dalam firman-Nya pada surat asSyu' ara ayat 80 :

$$
\text { وَإِذَا مَرِضْتُ فَهُهَ يَشْفِينِ }
$$

"Apabila aku sakit maka Dia (Allah) yang menyembuhkan". (QS. Al-Syu'ara'[26]: 80)

Kedua, keyakinan rezki anak yang tidak baik hanya dapat dirubah dengan melakukan tradisi jual beli anak. Keyakinan masyarakat Kabupaten Padang Pariaman tentang rezki anak yang tidak baik ini disebabkan kemiripan anak dengan orang tuanya. Kemiripan itu adalah anak laki-laki yang mirip ayahnya dan anak perempuan yang mirip ibunya, maka anak itu tidak memperoleh rezki yang baik. Untuk merubah kondisi tidak baik pada anak tersebut maka harus dilakukan tradisi jual beli anak.

Keyakinan seperti di atas bertentang dengan pernyatan Allah bahwa rezki seseorang itu sudah ditetapkan Allah dan tidak tergantung kepada orang lain, sebagaimana firman-Nya:

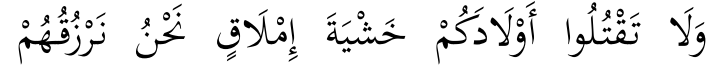

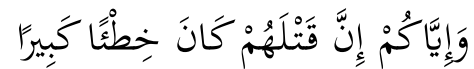

"Dan janganlah kamu membunuh anakanakmu karena takut kemiskinan. Hanya Kamilah yang akan memberi rezki kepada mereka dan juga kepadamu. Sesungguhnya membunuh mereka adalah suatu dosa yang besar". (Q.S. al-Isrâ'[17]: 31)

Ketiga, keyakinan masyarakat Kabupaten Padang Pariaman tentang kenakalan seorang anak disebabkan kemiripan anak dengan orang tuanya. Jika anak laki-laki yang mirip ayahnya dan anak perempuan yang mirip ibunya, maka anak itu sering berseberangan pendapat dengan orang tuanya. Jalan keluar dari kondisi ini adalah melakukan tradisi jual beli anak. Dengan melakukan tradisi jual beli anak maka anak yang nakal itu dapat berubah menjadi anak yang baik dan santun kepada orang tuanya. Pemahaman seperti ini tidak sesuai dengan pemahaman yang diberikan syari'at Islam bahwa baik dan buruknya kelakukan anak tergantung didikan oleh orang tuanya bukan disebabkan kemiripannya dengan orang tua tersebut. Hal ini ditegaskan oleh Hadits Rasulullah SAW: 


$$
\text { عن أبي هريرة رضي الله عنه قال قال النبي صلى الله }
$$

"Dari Abu Hurairah RA telah bersabda Nabi SAW: "Setiap anak yang lahir itu berada pada kondisi suci, maka orang tualah yang membentuknya berprilaku Yahudi, Nasrani dan Majusi". (Al-Bukhari, 1422: 100)

Keempat, keyakinan masyarakat Kabupaten Padang Pariaman bahwa tradisi jual beli anak itu dapat menyelesaikan persoalan masyarakat yang berkaitan dengan merubah nasib tidak baik yang terdapat pada seorang anak. Keyakinan semacam ini sudah menjadi kebiasan yang dilakukan secara turun temurun. Hal ini menegaskan bahwa masyarakat tidak lagi meminta pertolongan kepada Allah sebagai Tuhan mereka. Mereka menyakini bahwa perubahan nasib anak yang tidak baik itu dapat dilakukan oleh melalui pertolongan selain Allah, seperti telah dijelaskan di atas, dengan perantaraan tradisi jual beli anak. Kondisi ini sudah terjerumus kepada mempersekutukan Allah, padahal Allah telah mengingatkan bahwa mempersekutukan Allah adalah perbuatan dosa besar. Allah berfirman dalam surat an-Nisa' ayat 36 :

$$
\text { وَاعْبُدُوا اللَّهَ وَلَا تُشْرُكُوا بِِِ شَيْيًَا }
$$

"Sembahlah Allah dan jangan kamu persekutukan". (Q.S. An-Nisa'[4]: 36)

Peringatan Allah terdahulu dapat ditegaskan bahwa tradisi jual beli anak di Kabupaten Padang Pariaman yang membawa kepada keyakinan ada tempat meminta pertolongan selain Allah adalah perbuatan mempersekutukan Allah. Karena itu, tradisi jual beli anak di
Kabupaten Padang Pariaman tersebut bertentangan dengan ketentuan syara'.

Berdasarkan penilaian al-'Urf yang terdapat dalam syari'at Islam terhadap unsur jual beli dan keyakinan masyarakat terhadap tradisi jual beli anak di Kabupaten Padang Pariaman dapat disimpulkan bahwa tradisi jual beli anak di Kabupaten Padang Pariaman ini bertentangan dengan ketentuan yang terdapat dalam ajaran Islam. Karena itu, tradisi jual beli anak di Kabupaten Padang Pariaman termasuk dalam kategori al-'Urf al-Fasid (tradisi yang tidak diterima oleh syari' at Islam).

Tindak pidana jual beli anak secara khusus diatur dalam Pasal 76F UU No. 35 Tahun 2014 tentang Perubahan Pertama UU No.23 Tahun 2002 tentang Perlindungan Anak: "Setiap orang dilarang menempatkan, membiarkan, melakukan, menyuruh melakukan, atau turut serta melakukan penculikan, penjualan, dan/atau perdagangan anak".

Dapat diketahui bahwa unsur-unsur tindak pidana jual beli anak meliputi:

1. Unsur subjektif tindak pidana jual beli anak yaitu "Setiap orang". Setiap orang mempunyai makna bahwa pelaku tindak pidana jual beli anak adalah manusia.

2. Unsur objektif tindak pidana jual beli anak yaitu: "Dilarang menempatkan, membiarkan, melakukan, menyuruh melakukan, atau turut serta melakukan penculikan, penjualan, dan/atau perdagangan anak".

Undang-undang No. 35 Tahun 2014 tentang Perubahan Pertama UU No.23 Tahun 2002 tentang Perlindungan Anak, tidak menjelaskan makna dari penjualan/perdagangan anak secara jelas. 
Walaupun demikian, penjelasan makna jual beli anak dapat merujuk pada Pasal 1 UU No. 21 Tahun 2007 tentang Pemberantasan Tindak Pidana Perdagangan Orang, yaitu:

1. "Perdagangan Orang adalah tindakan perekrutan, pengangkutan, penampungan, pengiriman, pemindahan, atau penerimaan seseorang dengan ancaman kekerasan, penggunaan kekerasan, penculikan, penyekapan, pemalsuan, penipuan, penyalahgunaan kekuasaan atau posisi rentan, penjeratan utang atau memberi bayaran atau manfaat, sehingga memperoleh persetujuan dari orang yang memegang kendali atas orang lain tersebut, baik yang dilakukan di dalam negara maupun antar negara, untuk tujuan eksploitasi atau mengakibatkan orang tereksploitasi.

2. Tindak Pidana Perdagangan Orang adalah setiap tindakan atau serangkaian tindakan yang memenuhi unsur-unsur tindak pidana yang ditentukan dalam Undang-Undang ini."

Dari penjelasan Pasal 1 di atas, terdapat tiga unsur pokok sehingga dapat dikategorikan perdangan manusia, yaitu: proses, cara, dan tujuan (Hanifah: 2008, 49). Berikut tabelnya:

\begin{tabular}{|l|l|l|}
\hline Proses & Cara & Tujuan \\
\hline Perekrutan & Ancaman & Prostitusi \\
Pengiriman & Pemaksaan & Pornografi \\
Pemindahan & Penculikan & Kekerasan \\
Penampung & Penipuan & Eksploitasi \\
an & Kecurangan & Kerja \\
Penerimaan & Kebohongan & Perbudakan \\
& Penyalahguna & \\
& an Kekuasaan & \\
\hline
\end{tabular}

Adapun hasil penelitian lapangan tentang tradisi jual beli anak di Kabupaten Padang Pariaman tidak ada unsur perdagangan manusia baik dari segi proses, cara maupun tujuannya. Adapun prosesnya cuma pemberian sedikit uang sebagai syarat bukan untuk mendapakan keuntungan dan anak tetap berada pada orang tuanya. Sedangkan caranya tidak dengan melawan hukum seperti kekerasan, kecurangan, penipuan dan unsur syarat lainnya yang terdapat dalam Undang-Undang. Adapun tujuan dari tradisi jual beli anak adalah:

1. Membantu orang yang mempunyai anak agar anaknya menjadi sembuh dari penyakit yang diderita anak;

2. Sebagai tindakan prefentif mengatasi penyakit jika anak tersebut serupa dengan bapaknya;

3. Membantu orang yang mempunyai anak agar anaknya menjadi baik dan tidak nakal.

Berdasarkan penjelasan Pasal 1 angka 1 Undang-Undang No. 21 Tahun 2007 tentang Pemberantasan Tindak Pidana Perdagangan Orang dapat disimpulkan bahwa tradisi jual beli anak di Kabupaten Padang Pariaman tidak termasuk tindak pidana perdagangan anak, karena tidak terpenuhinya unsurunsur perdagangan manusia dalam UU No. 21 Tahun 2007 tentang Pemberantasan Tindak Pidana Perdagangan Orang.

Hal ini sejalan dengan defenisi tindak pidana perdagangan anak secara umum yaitu untuk mendapatkan keuntungan dari anak dan mengeksploitasi anak dengan cara memindahkan mereka dari lingkungan keluarga ke tempat yang terisolasi apakah dengan menggunakan kekerasan, penipuan ataupun tidak (Antonela Arhin, 2012: 162). 


\section{PENUTUP}

Tradisi jual beli anak di Kabupaten Padang Pariaman adalah kebiasaan masyarakat Kabupaten Padang Pariaman dengan tujuan menghilangkan kebiasan buruk seorang anak oleh orang tua kandungnya. Latar belakang tradisi jual beli anak di Kabupaten Padang Pariaman tidak diketahui secara pasti, namun indikasi di lapangan memberi petunjuk bahwa tradisi jual beli anak di Kabupaten Padang Pariaman dipengaruhi oleh keyakinan Hindu yang masih hidup dan berkembang di tengah masyarakat.

Penilaian al-'Urf yang terdapat dalam syari'at Islam terhadap unsur jual beli dan keyakinan masyarakat terhadap tradisi jual beli anak di Kabupaten Padang Pariaman. Tradisi jual beli anak ini bertentangan dengan ketentuan yang terdapat dalam ajaran Islam. Karena itu, tradisi jual beli anak di Kabupaten Padang Pariaman termasuk dalam kategori al-'Urf al-Fasid (tradisi yang tidak diterima oleh syari'at Islam). Sedangkan penilaian hukum pidana dapat disimpulkan bahwa tradisi jual beli anak di Kabupaten Padang Pariaman tidak termasuk tindak pidana perdagangan anak sebagaimana yang dijelaskan oleh Pasal 1 angka 1 UndangUndang No. 21 Tahun 2007 tentang Pemberantasan Tindak Pidana Perdagangan Orang, karena terpenuhinya unsur-unsur tindak pidana yang dijelaskan oleh Undang-undang.

\section{DAFTAR KEPUSTAKAAN}

Al-Bukharî al-Ju'fî, Muhammad bin 'Abdullah bin Isma'il. (1422 H). Shahih al-Bukhari. Dar Tuq an-Najah.
Al-Mahalî, Jalâl ad-Dîn Muhammad bin Ahmad dan as-Syuyûtî, Jalâl ad-Dîn 'Abdu ar-Rahman bin Abî Bakr. Tafsîr al-Jalâlain. (Tt). Kairo: Dâr alHadîs.

Al-Qurtubî, Abû 'Abdullâh Muhammad bin Ahmad bin Abî Bakr bin Farh alAnsharî Syams ad-Dîn selanjutnya dikenal dengan Imam al-Qurtubî. (2003). al-Jâmi' li Ahkâm al-Qur'ân, Dâr Alim al-Kutub.

An-Naysaburî, Abû Ishâq Ahmad bin Muhammad bin Ibrâhîm as-Tsa'labî. (2000). al-Kasyfu wa al-Bayân. Beirût: Dâr at-Turâst al-'Arabî.

Arhin, A. (2012). Conceptualizing Child Labour Trafficking and Exploitation: The Case of Roma Children in Montenegro. Temida, 15(3), 163-186.

At-Thabarî, Muhammad bin Jarîr bin Yazîd bin Katsîr bin Ghâlib Amalî Abû Ja'far. (2000). Tafsîr at-Thabarî fi Ta'wîl al-Qur'ân. Muastasah arRisâlah.

Az-Zuhailiy, Wahbah. (2005). al-Figh alIslamiy wa Adillatuh. Beirut: Dar alFikr.

Hamzawi, M. A. (2018). 'Urf dalam Kompilasi Hukum Islam Indonesia. Inovatif, 4(1).

Hanifah, A. (2008). Perdagangan Perempuan dan Anak: Kajian Faktor Penyebab dan Alternatif Pencegahannya. Jurnal Penelitian Dan Pengembangan Sosial, 13(2), 46-60.

Hasan, M. Iqbal. (2002). Pokok-Pokok Materi Metodologi Penelitiandan Aplikasinya. Jakarta: Ghalia Indonesia. 
Rahmat Hidayat, D. D. (2018). Studi Komparatif trehadap Ulama Hanafiyah dan Syafi'iyah tentang Wakaf Tunai. Al-Hurriyah (Jurnal Hukum Islam), 3(1).

Indrawati. (2015). Trafficking Kejahatan Terhadap Perempuan dan AnakAnak. Jurnal Cakrawala Hukum, 6(1), 36-44.

Majelis Ulama Indonesia dan UNICEF Jakarta. (1988). Memelihara Kelangsungan Hidup Anak Menurut Ajaran Islam. Jakarta: Panitia Muzakarah Ulama.

Miharja, J. (2011). Kaidah-kaidah al-Urf dalam Bidang Muamalah. El-Hikam (Jurnal Pendidikan Dan Kajian
Keislaman STAI Nurul Hakim Kediri), IV(1).

Anggraeni Putri, Nur Rochaeti, B. W. (2017). Perlindungan Hukum Bagi Anak Korban Tindak Pidana Perdagangan Manusia Berdasarkan Undang-Undang No.35 Tahun 2014 Tentang Perubahan Atas UndangUndang No.23 Tahun 2002 Tentang Perlindungan Anak. Diponegoro Law Journal, 6(1).

Soekanto, Soerdjono dan Masuji, Sri. (2006). Penelitian Hukum Normatif; Suatu Tinjauan Singkat. Jakarta: Raja Grafindo Persada. 